\title{
CYBER BULLYING AND VICTIMIZATION: A META ANALYTIC REVIEW
}

\author{
Nasla V.S * Nayana Mohan * Sannet Thomas** \\ *I MSc psychology students, Yuvashethra Institute of Management and Studies, Palakkad, \\ Kerala- 678631
}

**Assistant Professor of Yuvashethra Institute of Studies, PalakkadKerala-678631

Article DOI: https://doi.org/10.36713/epra6594

DOI No: 10.36713/epra6594

\begin{abstract}
Cyber bullying has become a critical social issue, which severely threatens children and adolescents' physical and psychological health. Cyber bullying has evolved from the increasing use of technology, specifically electronic communication and social networking. These findings enhance our understanding of the rates of occurrence of bullying, cyber bullying and victimization. Cyber bullying is defined as a means of bullying in which peers use electronic devices "to taunt, insult, threaten, harass, and/or intimidate a peer" (Raskauskas \& Stoltz, 2007, p. 565). With the growth of information and communication technology (ICT), bullying has expanded into the technological realm. Labelled as cyber bullying, individuals are utilizing technology, such as cellphones and the internet, to bully and cause harassment to others with the intention of causing harm. Ten studies which met the inclusion criteria were selected for this study. Findings of the study shows that it has an impact on both psychological and socio demographic problem.

KEYWORDS: cyber bullying victimization, media effects, meta-analysis, social cognition,cyber bullying perpetration, Harassment, Information and Communication Technology (ICT).
\end{abstract}

\section{DISCUSSION}

Cyber bullying refers to "an aggressive, intentional act carried out by a group or individual, using electronic forms of contact, repeatedly and over time against a victim who cannot easily defend him or herself' (Smith et al., 2008: 376).

Using this new form of bullying, known as cyber bullying, online harassment, or Internet bullying, bullies torment their victims in cyberspace with various forms of technology such as e-mails, instant messaging, chat rooms, and web sites. Text messaging over cell phones and phone cameras has also become new mediums for bullying (Campbell, 2005; Paulson, 2003; Peterson, 2002). It is being increasingly used to harm individuals (National Children's Home Study, 2002; Finkelhor, Mitchell, \& Wolak, 2000). Cyber bullying, like face-to-face bullying, can happen to groups as well as individuals. It is important to note that cyber bullying does not involve adults targeting minors; if adults are involved, it is no longer considered bullying and instead is considered cyber-stalking or sexual exploitation (in the case of adults trying to lure children or adolescents via technology for the purpose of engaging in sexual activities) (Finkelhor et al., 2000).

Rapid developments in information and communication technology have ushered in a technological transition in recent years (ICT). The benefits of these advances are manifold- such as increased availability of plethora of information, improved learning networks and resources for education, increased civic activity and public participation, development of social networks, friendships, etc., to name some of them (Kowalski et al., 2012a; Livingstone \& Haddon, 2009).

\section{IMPACT OF CYBER BULLYING}

The impact of cyber bullying among victims finds that the construct is a repeated behavior that offends, causes embarrassment, lowers self-esteem, sabotages, intimidates, and negatively affects an individual's academic, professional, personal and social life (Mesch, 2009). A range of problematic psychosocial health outcomes is associated with cyber bullying victimization including fear for their safety, increased distress, behavioral issues, drug abuse, psychosomatic problems like sleeping difficulties, headaches, bed-wetting, stomach aches, 
etc. Victimization increases one's likelihood of experiencing social and emotional loneliness (Brighi et al., 2012; Olenik-Shemesh, Heiman, \& Eden, 2012). Victims of cyber bullying and internet harassment also show signs of elevated depression (Bonanno \& Hymel, 2013; Machmutow, Perren, Sticca, \& Alsaker, 2012). Recent work shows victimization is associated with an elevated profile of cortisol, a physiological marker of stress, over aday (Gonzalez-Cabrera, Calvete, Leon-Mejía, PerezSancho, \& Peinado, 2016). Perhaps the most troubling association is that pervasive and ongoing cyber bullying victimization has been linked to suicidal ideation and suicide (Hinduja \& Patchin, 2010; Van Geel, Vedder, \& Tanilon, 2014).

The public nature of cyber bullying and not knowing who and how many people have seen or perpetrated the behaviour can impact the victims' perception (Gradinger, Strohmeier, \& Spiel, 2009; Tokunaga, 2010; Kowalski et al., 2012). The degree of impact can also be affected by the wide audience, anonymity, the permanence of a message (they can read it over and over, making it harder to forget), and the ability to reach the target 24/7 (Campbell, 2005; Kowalski et al., 2012; Menesini \& Nocentini, 2012).

One approach that has been widely debated as a successful step against cyber bullying is to integrate cyber bullying content into the curriculum. At another level, existing policies (anti-bullying, acceptable usage, etc.) need to be updated and accompanied by monitoring and sanctioning of unacceptable behaviour (Jager et al., 2010; Marczak $\&$ Coyne, 2010). Rather than trying to remove all risks (which is difficult to do), it would be better to help students cope by strategizing with them about how to avoid harm (Collier, 2012). When taking such acts, the role of parents and educators cannot be overlooked, and they must be active in the process.

\section{GENDER DIFFERENCES IN BULLYING AND CYBER BULLYING}

It's vital to assess whether there are gender gaps in the variable of interest, as in any childhood activity of concern. Since males and females create and respond to circumstances differently, this is essential information. We often need this knowledge in order to establish successful approaches that take into account gender differences. Currently, across cultures there are more male bullies than female bullies (Baldry\& Farrington, 2000; Hussein, 2010; Wei et al., 2009). Since boys tend to do more physical bullying, they may also be more likely to be caught in the act, versus girls who do more relational bullying. (Kert, Codding, Tyron \&Shiyko, 2010; Wei et al., 2009).
In a recent study by Pornari and Wood (2010) conducted in the United Kingdom, a questionnaire was given to 339 students in grades 7 through 9, which revealed that girls participate in cyber bullying at higher rates than boys. This was also found to be true across the United States, based on a large selfreport study of 3,767 students in 6th, 7th and 8th grades as well (Kowalski \& Limber, 2007).

\section{Objective}

1. To analyse research studies on cyber bullying and victimization and to have a deep understanding on the concept of Cyber bullying and victimization, and its related concepts.

\section{METHODOLOGY Literature Search}

A computer based information search was conducted on the Info Net- a computer database, which provides abstracts and full paper of articles. Studies from 2009 up to 2020 were covered in the search. Google scholar, Research gate, Scholar works,Science direct, Pubmed, ncbiand Frontiersin were searched "cyber bullying" and "victimization" as keywords to search for papers published from 2009 to 2020.Many studies were identified by the above keywords. Study abstracts obtained were read to eliminate studies that were not concerned with cyber bullying and victimization. These steps produced a pool of 10 studies that met inclusion criteria.

\section{Inclusion criteria}

The study aimed at understanding the concept of cyber bullying and victimization. Only full text studies were included. Qualitative studies, reviews, articles which focus mainly on cyber bullying and victimization were also included.

Another inclusion criterion was that study must be written in English language and finally the study must have been conducted between 2009 and 2020 .

Procedure

First of all the selected studies were arranged according to the year of publishing (from 2009 to 2020), then extracted major findings of the studies and then each study was analyzed qualitatively. These selected studies were arranged according to the publishing year. Then they are consolidated and analyzed using content analysis.

\section{RESULTS AND DISCUSSION}

The collected studies were arranged in the order of publication and analyzed using already identified factors and some factors were also emerged during the analysis process. The arrangement of selected studies and their classification were presented in table 1 . 


\begin{tabular}{|c|c|c|}
\hline SN Author(s) and year & Name of the study & Major findings \\
\hline $\begin{array}{l}\text { 1. Anika Mishra, \& } 2 \text { Dr. } \\
\text { Shivani Datta } \\
\text { Assistant Professor, Assistant } \\
\text { Professor } \\
\text { March 16, } 2019\end{array}$ & $\begin{array}{l}\text { Understanding the Experience } \\
\text { of Cyber bullying Victimisation } \\
\text { in Young } \\
\text { Adults }\end{array}$ & $\begin{array}{l}\text { This research identified main } \\
\text { findings such as the } \\
\text { - perpetrator's } \\
\text { anonymity in the } \\
\text { participants' worldview } \\
\text { - initial response, sense } \\
\text { of self and virtual } \\
\text { environment, } \\
\text { - current anxiety, coping } \\
\text { mechanism } \\
\text { - support system } \\
\text { - Learning from such } \\
\text { experiences. }\end{array}$ \\
\hline $\begin{array}{l}\text { 2.Calliope Athanasiou, Eirini } \\
\text { Melegkovits, Artemis K. Tsitsika } \\
\text { (10 July 2018) }\end{array}$ & $\begin{array}{l}\text { Cross-national aspects of cyber } \\
\text { bullying victimization among } \\
\text { 14-17-year-old adolescents } \\
\text { across seven European } \\
\text { countries }\end{array}$ & $\begin{array}{l}\text { Cyber bullying is a widespread } \\
\text { phenomenon that is shaped by } \\
\text { country-specific socio- } \\
\text { demographic factors as well as } \\
\text { existing Internet use and } \\
\text { development patterns. } \\
\text { Preventive strategies emphasise } \\
\text { the inclusion of Internet } \\
\text { communication technology } \\
\text { education into educational } \\
\text { settings, with a focus on the } \\
\text { strong connection between } \\
\text { cyber victimisation and } \\
\text { internalising and exterritorial } \\
\text { zing factors. }\end{array}$ \\
\hline $\begin{array}{l}\text { 3.Patricia A. Snell } \\
\text { Elizabeth Englander } \\
2010\end{array}$ & $\begin{array}{l}\text { Cyber bullying Victimization } \\
\text { and Behaviours' Among } \\
\text { Girls: Applying Research } \\
\text { Findings in the Field }\end{array}$ & $\begin{array}{l}\text { Females are more often } \\
\text { involved in cyber bullying } \\
\text { related activities, both as } \\
\text { victims and offenders, according } \\
\text { to previous studies and } \\
\text { preliminary findings in this } \\
\text { report. The } \\
\text { time spent on the internet and } \\
\text { on mobile phones } \\
\text { can be connected to the } \\
\text { incidence of these } \\
\text { 'Cyber bullying' is a phrase that } \\
\text { refers to the act of Aggression in } \\
\text { a relationship } \\
\text { Female-specific designs are also } \\
\text { recommended to have a } \\
\text { a connection between these } \\
\text { bullying styles. }\end{array}$ \\
\hline $\begin{array}{l}\text { 4. Koine AT, Saw YM, Htut ZY, } \\
\text { Khaing CT, Soe HZ, Swe KK, et } \\
\text { al. (2020) }\end{array}$ & $\begin{array}{l}\text { Assessing risk factors and } \\
\text { impact of cyber bullying } \\
\text { victimization among university } \\
\text { students in Myanmar: A cross- } \\
\text { sectional study }\end{array}$ & $\begin{array}{l}\text { In the last year, two out of every } \\
\text { five students have become } \\
\text { victims of cyber bullying. Non- } \\
\text { resident students and students } \\
\text { who had only been at the } \\
\text { university for three years or } \\
\text { less were more likely to be } \\
\text { victims of cyber bullying. }\end{array}$ \\
\hline
\end{tabular}




\begin{tabular}{|c|c|c|}
\hline & & $\begin{array}{l}\text { Students, who had experienced } \\
\text { psychological, physical, or } \\
\text { sexual abuse in their } \\
\text { communities, as well as cyber } \\
\text { bullying, were more likely to be } \\
\text { victims of cyber bullying. } \\
\text { Victims of cyber bullying were } \\
\text { found to have a strong } \\
\text { association with difficulties } \\
\text { focusing and understanding } \\
\text { lessons, as well as beginning or } \\
\text { growing drug abuse. }\end{array}$ \\
\hline $\begin{array}{l}\text { 5. Tan Kim Hua, Nicholas Sia } \\
\text { Heng Hwa, Sheau Tsuey Chong } \\
\text {, September } 2019\end{array}$ & $\begin{array}{l}\text { Cyber bullying Victimization } \\
\text { and Cyber bullying } \\
\text { Perpetration with Self-Esteem } \\
\text { as the Moderator }\end{array}$ & $\begin{array}{l}\text { The relationship between cyber } \\
\text { bullying victimisation and } \\
\text { perpetration was analysed } \\
\text { using hierarchical multiple } \\
\text { regressions, with self-esteem } \\
\text { serving as a moderating } \\
\text { variable. It also reveals whether } \\
\text { the moderator variable of self- } \\
\text { esteem truly moderates the } \\
\text { relationship between cyber } \\
\text { bullying perpetration and } \\
\text { victimisation. }\end{array}$ \\
\hline $\begin{array}{l}\text { 6. Bülent Dilmaç, Phd. Selcuk } \\
\text { University, } 2009\end{array}$ & $\begin{array}{l}\text { Psychological Needs as a } \\
\text { Predictor of } \\
\text { Cyber bullying: a Preliminary } \\
\text { Report on } \\
\text { College Students }\end{array}$ & \\
\hline $\begin{array}{l}\text { 7. Kaitlyn N. Ryan } \\
\text { and Tracey Curwen. } \\
\text { October-December } 2013\end{array}$ & $\begin{array}{l}\text { Cyber-Victimized Students: } \\
\text { Incidence, } \\
\text { Impact, and Intervention }\end{array}$ & $\begin{array}{l}\text { Bullying is a complex and } \\
\text { harmful problem for victims; } \\
\text { cyberbullying is no less } \\
\text { destructive and must be } \\
\text { handled from the victim's } \\
\text { viewpoint. According to } \\
\text { research, cyberbullying goals } \\
\text { and tactics vary depending on } \\
\text { the victim's age and gender, and } \\
\text { the victim's influence } \\
\text { encompasses social, mental, and } \\
\text { academic domains. }\end{array}$ \\
\hline $\begin{array}{l}\text { 8. Natalie Extremera, Cirenia } \\
\text { Quintana-Orts,, and Lourdes } \\
\text { Rey }\end{array}$ & $\begin{array}{l}\text { Cyber bullying Victimization, } \\
\text { Self-Esteem and Suicidal } \\
\text { Ideation in Adolescence: Does } \\
\text { Emotional Intelligence Play a } \\
\text { Buffering Role }\end{array}$ & $\begin{array}{l}\text { EI should be considered as a } \\
\text { personal resource that is } \\
\text { related to the negative } \\
\text { symptoms associated with } \\
\text { cyber bullying victimisation, } \\
\text { according to new study. Results } \\
\text { not only add to the theoretical } \\
\text { literature on cyber bullying and } \\
\text { its negative effects in } \\
\text { adolescence, but they also have } \\
\text { the potential to be used to build } \\
\text { school-based, integrated } \\
\text { bullying prevention strategies } \\
\text { aimed at enhancing adolescents' } \\
\text { emotional abilities in order to } \\
\text { defend against, or at least }\end{array}$ \\
\hline
\end{tabular}




\begin{tabular}{|c|c|c|}
\hline & & $\begin{array}{l}\text { reduce, the negative } \\
\text { consequences of becoming a } \\
\text { victim of cyber bullying. }\end{array}$ \\
\hline $\begin{array}{l}\text { 9. Eric Rice, PhD, Robin } \\
\text { Petering, MSW, and Timothy } \\
\text { Kordic, MA . } 2015\end{array}$ & $\begin{array}{l}\text { Cyber bullying Perpetration and } \\
\text { Victimization among Middle- } \\
\text { School Students }\end{array}$ & $\begin{array}{l}\text { The findings of this study point } \\
\text { to a variety of possible } \\
\text { intervention options. Since } \\
\text { middle-school students who are } \\
\text { active in cyber bullying (as } \\
\text { bullies or perpetrators-victims) } \\
\text { spend more time online than } \\
\text { their peers who are not, } \\
\text { restricting Internet usage can } \\
\text { help to reduce cyber bullying. } \\
\text { Furthermore, educational } \\
\text { services for teenagers who use } \\
\text { the Internet regularly could be } \\
\text { created and personalised. } \\
\text { Interventions should also take } \\
\text { into consideration the fact that } \\
\text { cyber bullying isn't about online } \\
\text { bullying. Unlike in-person } \\
\text { bullying, which is more } \\
\text { prevalent among boys, cyber } \\
\text { bullying was found to be more } \\
\text { common among girls in our } \\
\text { research. Concerningly, we } \\
\text { discovered that sexual-minority } \\
\text { students face a } \\
\text { disproportionately high risk of } \\
\text { cyber bullying victimisation. }\end{array}$ \\
\hline $\begin{array}{l}\text { 10. Sheryl A. Hemphill, Ph.D. } \\
\text { a,b, }{ }^{*} \text {, and Jessica A. Heerde, } \\
\text { April 21, } 2014\end{array}$ & $\begin{array}{l}\text { Adolescent Predictors of Young } \\
\text { Adult Cyber bullying } \\
\text { Perpetration } \\
\text { and Victimization Among } \\
\text { Australian Youth }\end{array}$ & $\begin{array}{l}\text { The current research looked at } \\
\text { adolescent predictors (ages } \\
\text { 14e15 years) of young adult } \\
\text { cyber bullying perpetration and } \\
\text { victimisation (ages } 18 \mathrm{e} 19 \\
\text { years). Grade } 9 \text { traditional } \\
\text { bullying perpetration, } \\
\text { traditional bullying } \\
\text { perpetration and victimisation, } \\
\text { and poor family management } \\
\text { were found to be predictors of } \\
\text { cyber bullying perpetration in } \\
\text { young adulthood. One teenage } \\
\text { predictor of cyber bullying } \\
\text { victimisation was discovered: } \\
\text { emotion regulation. In the } \\
\text { overall cyber bullying suspect } \\
\text { and victim group, there were } \\
\text { more young adult males than } \\
\text { females. }\end{array}$ \\
\hline
\end{tabular}

This meta-analysis not only examines the most significant predictors of cyber bullying perpetration and victimization, but it also explores the extent of these predictors' impacts. Specifically, the findings showed that all of the proposed variables from how cyber bullying and victimization impact young adults, gender, adolescents, and emotion were found to be important. 
This research was important because it identified basic themes or main findings such as the perpetrator's anonymity in the participants' worldview, initial response, sense of self and virtual environment, current anxiety, coping mechanism, support system, and learning from such experiences, all of which contributed to the current literature and awareness on the effect of cyber bullying on young adults.

Cyber bullying is a recurrent issue that is affected by country-specific socio-demographic factors as well as various trends of existing Internet usage and growth. Preventive initiatives should concentrate on the consistent connection between cyber victimization and internalising and externalising difficulties, as well as the inclusion of Internet communication technology education in educational contexts.

Females are more often involved in cyber bullying related activities, both as victims and offenders, according to previous studies and preliminary findings in this report. The amount of time spent on the internet and on mobile phones may be connected to the incidence of cyber bullying. Female relational violence types are believed to be related to these bullying behaviours. Gender patterns in cyber bullying need to be investigated further. Students and faculty may receive training and education to help raise awareness about cyber bullying.' In the last year, two out of every five students have become victims of cyber bullying. Non-resident students and students who had only been at the university for three years or less were more likely to be victims of cyber bullying. Students, who had experienced psychological, physical, or sexual abuse in their communities, as well as cyber bullying, were more likely to be victims of cyber bullying. Victims of cyber bullying were found to have a strong association with difficulties focusing and understanding lessons, as well as beginning or growing drug abuse. For university students in Myanmar, periodic screening for cyber bullying, counselling facilities, cyber-safety educational programmes, and awareness raising campaigns are urgently needed.

The relationship between cyber bullying victimisation and perpetration was analysed using hierarchical multiple regressions, with self-esteem serving as the moderating variable. It also reveals whether the moderator variable of self-esteem truly moderates the relationship between cyber bullying perpetration and cyber bullying victimisation. The relationship between cyber bullying and college students' psychological needs. There was little theoretical history in this field of research prior to this study. This research attempted to fill the void. Aggression and succorance were found to be positive predictors of cyber bullying, while interception was found to be a negative predictor. Endurance and dedication the risk of becoming a target of cybercrime was expected to be negative. Just the "need for reform" positively expected cybercrime. The participants' homogeneous ethnicity and socioeconomic history is one study's limitation. As a consequence, replication and comparative studies are needed. However, based on the current literature and the results of this research, aggression and violence are related.

Bullying is a complex and harmful problem for victims; cyber bullying is no less damaging and must be handled from the victim's viewpoint. According to research, cyber bullying goals and tactics vary depending on the victim's age and gender, and the victim's influence encompasses social, mental, and academic domains.

Despite these shortcomings, our findings contribute to the growing body of evidence that EI should be considered a personal resource related to the negative symptoms of cyber bullying victimisation. Our results not only add to the theoretical literature on cyber bullying and its negative effects in adolescence, but they also have the potential to be used to build school-based, integrated bullying prevention strategies aimed at enhancing adolescents' emotional abilities in order to defend against, or at least reduce, the negative consequences of becoming a victim of cyber bullying.

The findings of this study point to a variety of possible intervention options. Since middle-school students who are active in cyber bullying (as bullies or perpetrators-victims) spend more time online than their peers who are not, restricting Internet usage can help to reduce cyber bullying. Furthermore, educational services for adolescents may be created and customised. Interventions should also take into consideration the fact that cyber bullying isn't about online bullying. Unlike in-person bullying, which is more prevalent among boys, cyber bullying was found to be more common among girls in our research. We discovered that sexual-minority students were at a substantially higher risk of becoming victims of cyber bullying.

Adolescent predictors of young adult (age, 1819 years) cyber bullying perpetration and victimisation (age, 14-15 years). Grade 9 traditional bullying perpetration, traditional bullying perpetration and victimisation, and poor family management were found to be predictors of cyber bullying perpetration in young adulthood. One teenage predictor of cyber bullying victimisation was discovered: emotion regulation. In the overall cyber bullying suspect and victim group, there were more young adult males than females.

\section{CONCLUSION}

Reviewing the literature has given me a
deeper understanding of cyberbullying and 
victimization. The majority of studies showed that all writers approached the subject from various perspectives.

This meta-analysis not only examines the most significant predictors of cyber bullying perpetration and victimisation, but it also explores the extent of these predictors' impacts. Specifically, the findings showed that all of the proposed variables from how cyber bullying and victimisation impact young adults, gender, adolescents, and emotion were found to be important.

\section{Implication and suggestions}

The findings of this meta-analysis present some practical implications for educators and parents. Additionally, this meta-analysis provides guidelines for the direction of future cyber bullying research. Future studies should focus on examining cyber bullying on social media. Next, while many children have become offenders and victims of cyber bullying; only a few studies examined predictors of cyber bullying perpetration or victimization in childhood.

This meta-analysis' results have some practical consequences for teachers and parents. In addition, the results of this meta-analysis provide direction for future cyber bullying studies. Future research should look at cyber bullying on social media. Next, while many children have been both perpetrators and victims of cyber bullying, only a few studies have looked into the factors that affect cyber bullying. This meta-analysis' results have some practical consequences for teachers and parents. In addition, the results of this meta-analysis provide direction for future cyber bullying studies. Future research should look at cyber bullying on social media. Next, while many children have been both perpetrators and victims of cyber bullying, only a few studies have looked into the factors that affect cyber bullying..

\section{REFERENCES}

1. Athanasiou, K., Melegkovits, E., Andrie, E. K., Magoulas, C., Tzavara, C. K., Richardson, C., ... \& Tsitsika, A. K. (2018). Cross-national aspects of cyber bullying victimization among 14-17-year-old adolescents across seven European countries. BMC public health, 18(1), 1-15.

2. Snell, P. A., \& Englander, E. (2010). Cyber bullying victimization and behaviors among girls: Applying research findings in the field. Journal of social sciences.

3. Khine, A. T., Saw, Y. M., Htut, Z. Y., Khaing, C. T., Soe, H. Z., Swe, K. K., ... \& Hamajima, N. (2020). Assessing risk factors and impact of cyber bullying victimization among university students in Myanmar: A cross-sectional study. PloS one, 15(1), e0227051.
4. Dilmac, B. (2009). Psychological needs as a predictor of cyber bullying: A preliminary report on college students. Educational Sciences: Theory and Practice, 9(3), 13071325.

5. Ryan, K. N., \& Curwen, T. (2013). Cybervictimized students: Incidence, impact, and intervention. SAGE 2158244013516772.

6. Extremera, N., Quintana-Orts, C., MéridaLópez, S., \& Rey, L. (2018). Cyber bullying victimization, self-esteem and suicidal ideation in adolescence: Does emotional intelligence play a buffering role?. Frontiers in psychology, 9, 367.

7. Hemphill, S. A., \& Heerde, J. A. (2014). Adolescent predictors of young adult cyber bullying perpetration and victimization among Australian youth. Journal of Adolescent Health, 55(4), 580-587.

8. Rice, E., Petering, R., Rhoades, H., Winetrobe, H., Goldbach, J., Plant, A., ... \& Kordic, T. (2015). Cyber bullying perpetration and victimization among middle-school students. American journal of public health, 105(3), e66-e72. 